\title{
Effect of Influent Ratio on Anaerobic Treatment of Coal Gasification Wastewater
}

\author{
Shi-dong Yang ${ }^{1, a}$, Wen-xin Tao ${ }^{2, b,{ }^{*}}$ and Lu-hua Liao ${ }^{3, c}$ \\ ${ }^{1,2}$ School of Civil Engineering and Architecture Northeast Electric Power University Jilin132012, \\ China \\ ${ }^{3}$ GuangXi Polytechnic of Construction, Nanning530005,China \\ a15981105115@163.com, b837800577@qq.com, '1329689755@qq.com
}

\begin{abstract}
Keywords: coal gasification wastewater, anaerobic ammonium oxidation, denitrification, influent
\end{abstract} ratio, removal of carbon and nitrogen.

\begin{abstract}
The synactic effect of anammox coupling with heterotrophic denitrification process was investigated in an anaerobic reactor with an influent at the temperature of $35^{\circ} \mathrm{C}, \mathrm{pH}$ of 7.0 , hydraulic detention time (HRT) of $30 \mathrm{~h}$. The nitrate and nitrite solution with different ratio $(\mathrm{R}=0-100 \%)$ to raw waste water was introduced into the influent with ammonia of 70-120 mg/L, COD concentration of $800-1200 \mathrm{mg} / \mathrm{L}$ before entering the anaerobic reactor to investigate the removal of nitrogen and organics. The experimental results show that in the influent ratio is $75 \%$, the removal of ammonia, nitrite, total nitrogen (TN) and COD can reach 55.71\%, 63.65\%, 64.56\% and 80\%, respectively, under the condition of ammonia nitrogen, nitrite nitrogen influent concentration of 75.43mg/L99.87mg/La TN load of $233.82 \mathrm{mg} /(\mathrm{L} \cdot \mathrm{d})$. The results show that the optimum dilution can not only dilute the raw waste water but also achieve co-effect of anammox and anaerobic denitrification by dosing appropriate nitrate and nitrate.
\end{abstract}

\section{Introduction}

Anaerobic ammonium oxidation process(ANAMMOX) is a promising biological nitrogen removal technology [1][2]. Compared with the traditional biological denitrification technology, it has the advantages of low oxygen demand, low operating cost, no additional carbon source, less sludge production and so on [3][4]. The process uses nitrite as electron acceptor under anaerobic or anoxic conditions, and the ammonia is converted to the biological processes of nitrogen [5]. Due to the anaerobic ammonia oxidizing bacteria is autotrophic, the activity of anammox bacteria will be inhibited under the condition of high concentration of organic carbon source and seriously affected on the removal effect of nitrogen [6]. Coal gasification wastewater [7][8][9] is a kind of typical organic wastewater which is hard to be degraded by high ammonia and phenol concentration, causing difficulties in achieving anaerobic ammonium oxidation. So it is very important to study the coupling of anaerobic ammonium oxidation and denitrification to achieve the simultaneous removal of nitrogen and organics. Large quantities of organic compounds (such as glucose) will seriously affected the ANAMMOX process although small amount organics have slight effect on ammonium oxidation [10]. The activated sludge could show a high denitrification activity while the anaerobic ammonium oxidation activity is inhibited. Some studies shown that the coupling of anaerobic ammonium oxidation and denitrification in the presence of phenol is also feasible [11]. Although there is competition of the same substrate of nitrite between the two processes, the presence of the denitrification bacteria can remove the inhibition effect of organic compounds on anaerobic ammonium oxidizing bacteria. The denitrification bacteria exist in the anoxic conditions can consume a small amount of $\mathrm{O}_{2}$ introduced into the water and decrease the effect of $\mathrm{O}_{2}$ on the anaerobic ammonium oxidizing bacteria. At the same time, the $\mathrm{CO}_{2}$ produced by denitrification can provide inorganic carbon source for anaerobic bacteria. The nitrate produced by the anaerobic ammonium oxidation reaction can provide the substrate for denitrification. All the processes can achieve the goal of simultaneous denitrification and carbon removal in competition. 
The study on the performance of anaerobic ammonium oxidation and denitrification has been rarely reported under the condition of high concentration organic carbon source. The coal gasification wastewater is a typical high ammonia wastewater containing phenol. The simulated coal gasification wastewater was used to study the effect of anaerobic ammonium oxidation coupled with the heterotrophic denitrification in anaerobic reactor. Because of the high concentration of ammonia nitrogen and COD concentration in the raw water, the nitrite content is very small, nitrite was introduced into the anaerobic stage to achieve the ammonia oxidation. Also the nitrate was introduced to investigate the possibility of anaerobic denitrification. The artificial water with nitrite and nitrate concentration was introduced into the anaerobic reactor according to the ratio of $\mathrm{R}$ in order to study the effect of nitrogen removal in anaerobic phase.

\section{Materials and methods}

\subsection{Experimental apparatus}

The effective volume of anaerobic reactor was $2.5 \mathrm{~L}$ with the height of $40 \mathrm{~cm}$ and the diameter of $10 \mathrm{~cm}$. The creeping pump is used to control flow rate. The reactor was operated at about $35^{\circ} \mathrm{C}$ in a water bath and covered with black cloth to avoid light. The HRT was 30h. The influent pH was controlled by the $\mathrm{NaOH}$ and the $\mathrm{HCl}$ around 7 .

\subsection{Simulated wastewater}

Artificial water was used in the experiment and influent composition of anaerobic reactor were composed by: glucose $230-250 \mathrm{mg} / \mathrm{L}$, volatile phenol $150-250 \mathrm{mg} / \mathrm{L}$, ammonia nitrogen $100-200 \mathrm{mg} / \mathrm{L}$, thiocyanat $20-50 \mathrm{mg} / \mathrm{L}$, sulfide $20-50 \mathrm{mg} / \mathrm{L}$, pyridine compounds $20-40 \mathrm{mg} / \mathrm{L}$, Furan compounds 20-40mg/L, benzpyrole compounds 20-30mg/L, Benzene compounds 100-150mg/L, KH2PO $27 \mathrm{mg} / \mathrm{L}, \quad \mathrm{CaCl}_{2} \cdot 2 \mathrm{H}_{2} \mathrm{O} \quad 180 \mathrm{mg} / \mathrm{L}, \quad \mathrm{MgSO}_{4} \cdot 7 \mathrm{H}_{2} \mathrm{O} \quad 300 \mathrm{mg} / \mathrm{L}, \quad \mathrm{NaHCO}_{3} \quad 0.5 \mathrm{~g} / \mathrm{L}$. Trace element concentration liquid I and trace element I I concentration $1 \mathrm{ml} / \mathrm{L}$ [12].

\subsection{Measurement}

Water quality parameters were tested according to The Standard Methods for Water and Wastewater Quality Monitoring (Fourth Edition). The COD, $\mathrm{NH}_{4}{ }^{+}-\mathrm{N} \mathrm{NO}_{2}{ }^{-}-\mathrm{N} \mathrm{NO}_{3}-\mathrm{N}$ TN and total phenol and volatile phenol were determined by fast closed catalytic digestion method, Nessler's Reagent spectrophotometric method, N-(1-naphthyl) ethylenediamine dihydrochloride spectrophotometric method, UV spectrophotometry, alkaline potassium sulfate oxidation UV spectrophotometry; 4-aminoantipyrine direct spectrophotometric method, UV spectrophotometry, respectively. All charts and data were analyzed and processed with the Origin 8.5 software.

\subsection{Experimental procedure}

The anaerobic reactor has been operated for six months. The optimum operating conditions were determined by orthogonal experiments. Volatile phenols, total phenols and COD influent concentrations were 200 240mg/L, 390 420mg/L and 1400 1600mg/L, respectively. The removal rates were $48.35 \%, 51.37 \%$ and $51.63 \%$., respectively. In order to reduce the inhibitory effect of high concentration organic compounds on the anaerobic ammonium oxidation under the best anaerobic environment, another influent containing nitrite nitrogen and nitrate nitrogen was introduced into the anaerobic reactor to dilute the influent anaerobic water and provide nitrite the same time, achieving the coupling of anaerobic ammonium oxidation, denitrification and heterotrophic anaerobic bacteria and simultaneous removal of organic matter and nitrogen. The influent dilution ratio $\mathrm{R}$ is the influent including the nitrite and nitrate to the simulated influent flow. Nitrite and nitrate in artificial water were supplied by $\mathrm{NaNO}_{2}$ and $\mathrm{NaNO}_{3}$. Both influents were made by tap water and imported by peristalsis pump into the anaerobic reactor bottom.

The ammonia nitrogen concentration was kept at $130 \sim 150 \mathrm{mg} / \mathrm{L}$ in raw water. Then designed different influent dilution ratio $\mathrm{R}$ were taken $25 \%, 50 \%, 75 \%, 100 \%$. The influent and outlet 
concentrations of ammonia, volatile phenol, and the dilution in the total reactor under different ratio of $\mathrm{R}$ were analyzed.The anaerobic reactor was operated continuously for about 10 days under each different ratio of R. For the convenience of data processing, the ammonia, volatile phenol, total phenol, COD concentration were caculated by dilute concentration after the artificial water distribution influent in the anaerobic reactor. The $\mathrm{NO}_{2}{ }^{-}-\mathrm{N} / \mathrm{NH}_{4}{ }^{+}-\mathrm{N}$ mass concentration ratio was controlled at 1:1.32.

\section{Result and discussion}

\subsection{Effect of $R$ on nitrogen removal}

The influent water and effluent water quality was shown in Fig. 1 for 1 11d, 12 19d, 20 29d, $30 \sim 40 \mathrm{~d}$ corresponding to the influent ratio of $\mathrm{R}$ were $25 \%, 50 \%, 75 \%, 100 \%$, respectively, including the $\mathrm{NH}_{4}{ }^{+}-\mathrm{N}, \mathrm{NO}_{2}^{-}-\mathrm{N}, \mathrm{NO}_{3}{ }^{-}-\mathrm{N}, \mathrm{TN}$ concentration and the removal tendency.

Figure 1 shows that at the ratio of $25 \%, 50 \%, \mathrm{NH}_{4}{ }^{+}-\mathrm{N}, \mathrm{NO}_{2}{ }^{-}-\mathrm{N}$, TN of the effluent were not stable except $\mathrm{NO}_{3}{ }^{-}-\mathrm{N}$. At the ratio of $75 \%, 100 \%, \mathrm{NH}_{4}{ }^{+}-\mathrm{N}, \mathrm{NO}_{2}{ }^{-}-\mathrm{N}, \mathrm{NO}_{3}{ }^{-}-\mathrm{N}, \mathrm{TN}$ of the effluent water were relatively stable. $\mathrm{NO}_{2}^{-}-\mathrm{N}$, TN of the effluent concentration is the lowest at the ratio of $75 \%$, while the concentration of ammonia nitrogen is only $3 \mathrm{mg} / \mathrm{L}$ higher than that at the ratio of $100 \%$.

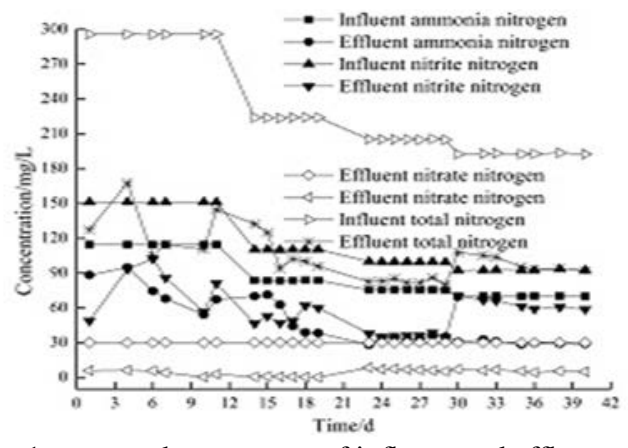

Fig. 1 content change curve of influent and effluent $\mathrm{NH}_{4}{ }^{+}-\mathrm{N}, \mathrm{NO}_{2}^{-}-\mathrm{N}, \mathrm{NO}_{3}^{-}-\mathrm{N}, \mathrm{TN}$

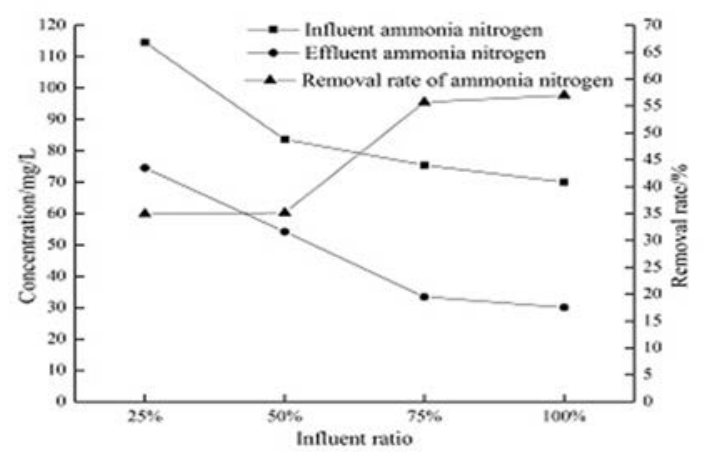

Fig. 2 influent ratio on $\mathrm{NH}_{4}{ }^{+}-\mathrm{N}$ removal

With the increase in the proportion of water, ammonia nitrogen removal rate showed an upward trend in Fig. 2. When the ratio increased from 50\% to $75 \%$, the removal rate increased nearly $20 \%$ to the maximum value. The removal of ammonia nitrogen is also the largest at the $R$ of $75 \%$. Fig. 3 also shows a maximum removal of nitrite at the influent ratio of $75 \%$. When the influent ratio is $25 \% \sim 75 \%$, the removal rate is linear dependent on $R$. When the influent ratio increased from $75 \%$ to $100 \%$, the removal rate appeared to be greatly reduced from $63.65 \%$ to $31.58 \%$.

Fig. 3 and 4 shows some difference between effects of $\mathrm{R}$ on nitrite and nitrate. When the influent concentration of nitrate was about $30 \mathrm{mg} / \mathrm{L}$ and the influent ratio was $50 \%$, the average removal rate was the highest up to $98.97 \%$. In the contrast, the removal rate of nitrate was the lowest when the ratio of nitrate was $75 \%$, and the average removal rate was $77.52 \%$. The total nitrogen removal was similar with nitrite, when the removal rate could reach a maximum value of $64.56 \%$ at $R=75 \%$. When the influent ratio is $100 \%$, the removal rate of $\mathrm{TN}$ was the lowest with an average value of $48.76 \%$.

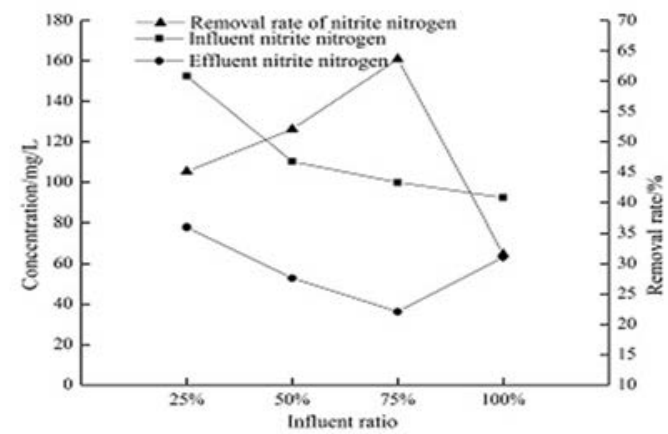

Fig. 3 influent ratio on $\mathrm{NO}_{2}^{-}-\mathrm{N}$ removal

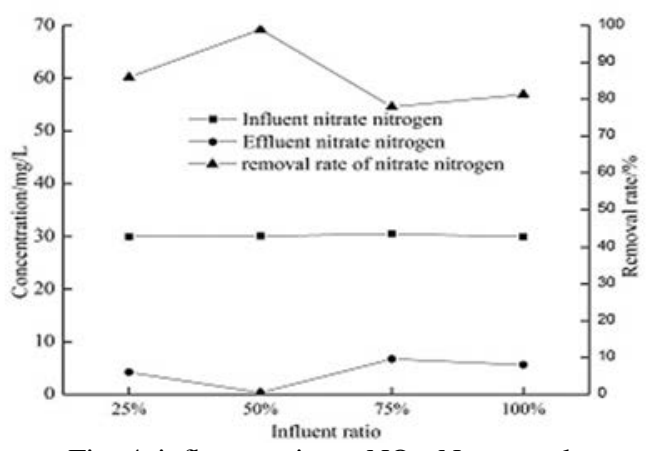

Fig. 4 influent ratio on $\mathrm{NO}_{3}^{-}-\mathrm{N}$ removal 


\section{2 the effect of different influent ratio of $R$ on nitrogen removal}

$\mathrm{NH}_{4}{ }^{+}-\mathrm{N}, \mathrm{NO}_{2}^{-}-\mathrm{N}$ are the substrate for the anaerobic ammonium oxidation reaction and $\mathrm{NO}_{2}^{-}-\mathrm{N}$, $\mathrm{NO}_{3}{ }^{-}-\mathrm{N}$ are the substrate for denitrification. The $\mathrm{NH}_{4}{ }^{+}-\mathrm{N}$ was chosen as a reference to measure the proportion of anaerobic ammonium oxidation reactions in the coupling. Fig. 6 shows that when the influent ratio was $25 \%$, ammonia removed was $40.02 \mathrm{mg} / \mathrm{L}$, the nitrite and nitrate removed were $74.65 \mathrm{mg} / \mathrm{L}$ and $25.79 \mathrm{mg} / \mathrm{L}$, respectively. Nitrite reduced by ANAMMOX should be 52.83mg/L which could be calculated theoretically by ammonia oxidized. Accordingly the formation of nitrate was10.41mg/L. Totally $21.82 \mathrm{mg} / \mathrm{L}$ nitrite was removed through denitrification. So the total nitrogen involved in denitrification was $58.02 \mathrm{mg} / \mathrm{L}$, which accounted for $33.99 \%$ of the total nitrogen removal rate. Among them, the denitrification of nitrite as electron acceptor accounted for $12.78 \%$ of the total nitrogen removal, and the contribution of anaerobic ammonium oxidation to total nitrogen removal rate was $66.01 \%$. When $\mathrm{R}=50 \%, 75 \%$, contributions of nitrogen removal could be calculated as above, which was shown in Fig. 6.

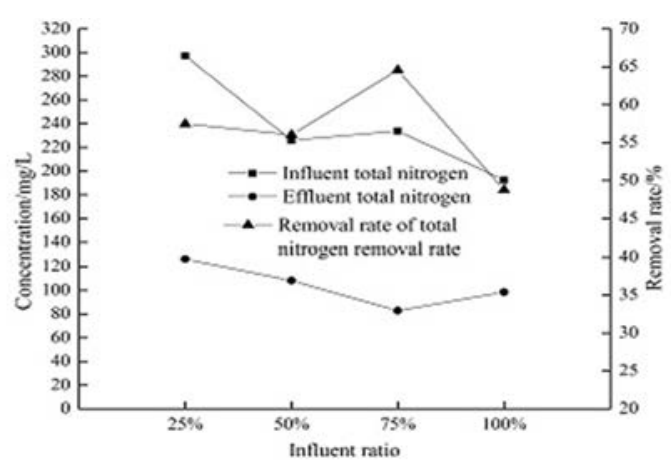

Fig. 5 influent ratio on TN removal

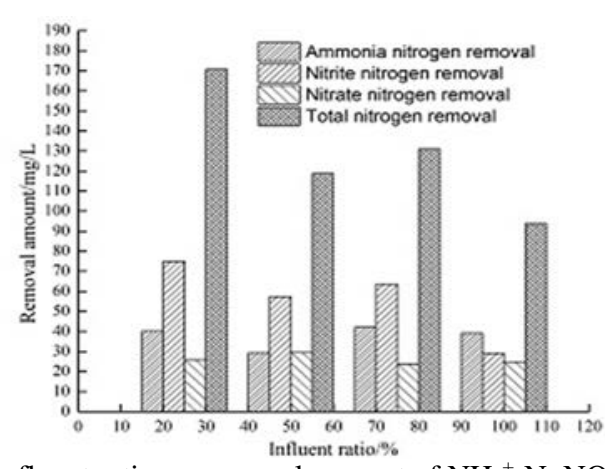

Fig. 6 influent ratio on removal amount of $\mathrm{NH}_{4}{ }^{+}-\mathrm{N}, \mathrm{NO}_{2}{ }^{-}-\mathrm{N}$, $\mathrm{NO}_{3}^{-}-\mathrm{N}, \mathrm{TN}$

When the water inlet ratio is $100 \%$, the nitrogen removal condition is different from above. The removed $\mathrm{NH}_{4}{ }^{+}-\mathrm{N}$ was $39.9 \mathrm{mg} / \mathrm{L}$, and the effluent concentration of $\mathrm{NO}_{2}{ }^{-}-\mathrm{N}, \mathrm{NO}_{3}{ }^{-}-\mathrm{N}$ were $63.22 \mathrm{mg} / \mathrm{L}$, $5.62 \mathrm{mg} / \mathrm{L}$, respectively The amount of nitrite consumed in the anaerobic ammonium oxidation reaction was caculated by consumption of ammonia as $52.67 \mathrm{mg} / \mathrm{L}$, less than that of the influent concentration of $92.4 \mathrm{mg} / \mathrm{L}$. Accumulation of nitrite occured at this influent ratio, which was caused by partial denitrification of nitrate. The total amount of the nitrate in the effluent and the nitrite consumed by anaerobic ammonium oxidation were $115.89 \mathrm{mg} / \mathrm{L}$, while that of the influent is $92.4 \mathrm{mg} / \mathrm{L}$. The production of nitrite from the denitrification was $23.49 \mathrm{mg} / \mathrm{L}$. The nitrate in anaerobic ammonium oxidation was $10.16 \mathrm{mg} / \mathrm{L}$, and that in the influent was $30 \mathrm{mg} / \mathrm{L}$. The total amount of actual nitrate nitrogen was $40.16 \mathrm{mg} / \mathrm{L}$, while the effluent nitrate nitrogen was $5.62 \mathrm{mg} / \mathrm{L}$. So the nitrate nitrogen in the process of complete denitrification was $11.05 \mathrm{mg} / \mathrm{L}$, which accounted for $11.78 \%$ in the total nitrogen removal. Nitrogen removed by anaerobic ammonium oxidation accounted for $88.22 \%$ of the total nitrogen removal. The final calculation results were shown in Table 1.

Table 1 calculation results of anaerobic ammonium oxidation and denitrification on nitrogen removal $(\mathrm{mg} / \mathrm{L})$

\begin{tabular}{rcrccc}
\hline $\begin{array}{l}\text { Influent } \\
\text { ratio R }\end{array}$ & $\begin{array}{l}\text { Consu } \\
\text { me }\end{array}$ & $\begin{array}{c}\text { Theory } \\
\mathrm{NO}_{2}{ }^{-}-\mathrm{N}\end{array}$ & $\begin{array}{l}\text { Produce } \\
\mathrm{NO}_{3}{ }^{-}-\mathrm{N}\end{array}$ & $\begin{array}{l}\text { Total } \\
\mathrm{NO}_{3}{ }^{-} \mathrm{N}\end{array}$ & $\begin{array}{l}\text { denitrificati } \\
\text { onNO }\end{array}{ }^{-}-\mathrm{N}$ \\
\hline $25 \%$ & 40.02 & 52.83 & 10.41 & 36.20 & 58.02 \\
$50 \%$ & 29.37 & 42.33 & 7.55 & 37.01 & 52.08 \\
$75 \%$ & 43.02 & 55.47 & 10.93 & 34.19 & 42.29 \\
$100 \%$ & 39.90 & 52.67 & 10.16 & 35.44 & 11.05 \\
\hline
\end{tabular}

\subsection{Effect of $R$ on organics removal}

The concentrations of volatile phenols, total phenols, COD in the influent and effluent were shown in Fig. 7 . When the ratio of volatile phenols and total phenols increased from $25 \%$ to $50 \%$, the volatile 
phenols removal was not improved, and the removed COD was also reduced by about $80 \mathrm{mg} / \mathrm{L}$. This might be caused by adding nitrate and nitrite solution in the early stage, causing the changes in the influent ORP. Increased ORP had negative effect on anaerobic bacteria, causing decrease of phenol removal. When the influent ratio increased from $50 \%$ to $75 \%$, the removal efficiency increased significantly, for exampe, the removal of COD increased about $30 \mathrm{mg} / \mathrm{L}, 50 \mathrm{mg} / \mathrm{L}$ compared with the influent ratio of $25 \%$ and $50 \%$, respectively. This was due to the introduction of nitrate and nitrite in the period of about 20 days, some anaerobic bacteria adapted to the conditions of the raw water. Or the bacteria population got adapted to the influent, causing recovery of the activity and phenol removal. With increased influent ratio, the removal improvement was not obvious. The concentration of volatile phenol in effluent was still at about $20 \mathrm{mg} / \mathrm{L}$, and the removal rate of total phenol concentration was not significantly increased either. On the contrary, removal rate of COD decreased with the increased $R$.

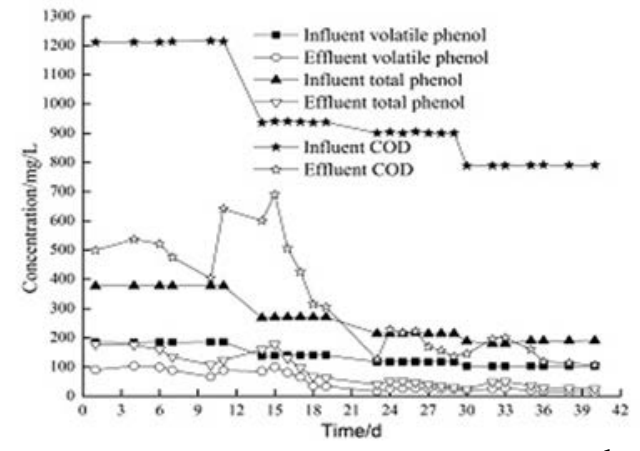

Fig.7 content change curve of influent and effluent phenol, COD

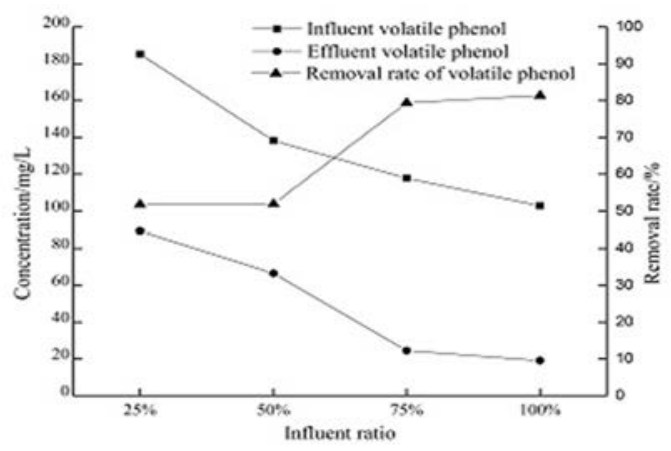

Fig.8 influent ratio on volatiel phenol removal

From the Fig. 8 and 9, we could see that the removal of volatile phenol and total phenol with the increased influent ratio was almost the same. The removal efficiency of organic matters was the best between $75 \%$ and $100 \%$. COD removal could reach the maximum of $721.29 \mathrm{mg} / \mathrm{L}$ when $\mathrm{R}=75 \%$.

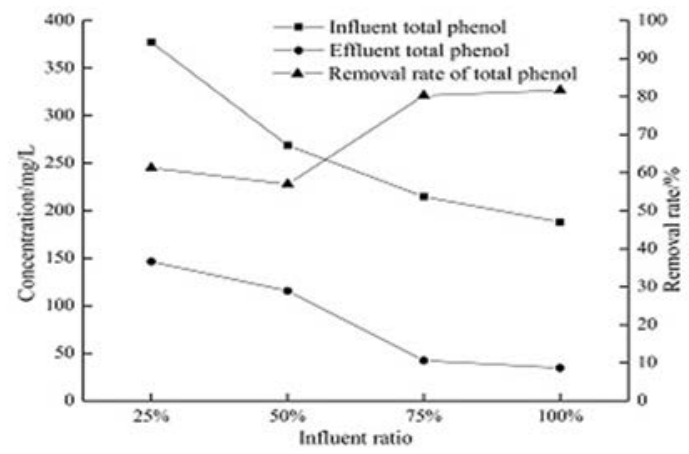

Fig.9 influent ratio on total phenol removal

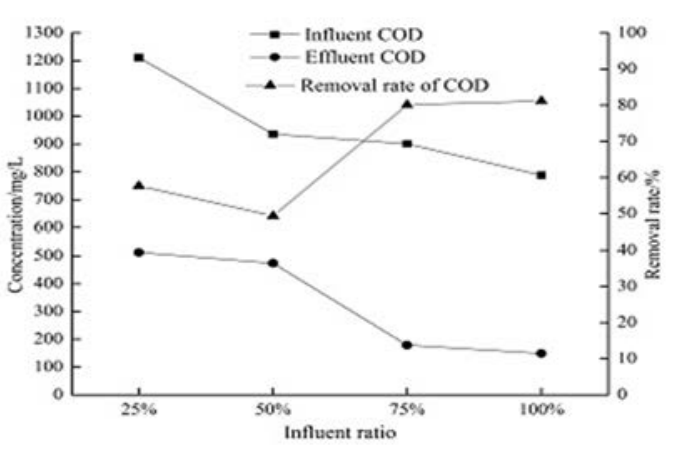

Fig.10 influent ratio on COD removal

From the theoretical equation of denitrification reaction, the decomposition of $1 \mathrm{mg}$ organic matter (COD) requires $0.58 \mathrm{mg} \mathrm{NO}_{3}{ }^{-} \mathrm{N}$ and $0.35 \mathrm{mg} \mathrm{NO}_{2}{ }^{-}-\mathrm{N}$. The amount of COD consumed can be calculated by analyzing nitrogen removed, which was shown in Table 2.

Table 2 COD removed in denitrification ( $\mathrm{mg} / \mathrm{L}$ )

\begin{tabular}{cccccc}
\hline $\begin{array}{c}\text { Influent } \\
\text { ratio R }\end{array}$ & $\begin{array}{c}\text { Consu } \\
\text { med } \\
\mathrm{NO}_{2}^{-}-\mathrm{N}\end{array}$ & $\begin{array}{c}\text { Consu } \\
\text { med } \\
\mathrm{NO}_{3}^{-}-\mathrm{N}\end{array}$ & $\begin{array}{c}\mathrm{NO}_{2}^{-} \mathrm{N} \\
\text { Consumed } \\
\text { COD }\end{array}$ & $\begin{array}{c}\mathrm{NO}_{3}{ }^{-} \mathrm{N} \\
\text { Consumed } \\
\text { COD }\end{array}$ & $\begin{array}{c}\mathrm{NO}_{x}^{-}-\mathrm{N} \\
\text { Consumed COD }\end{array}$ \\
\hline $25 \%$ & 21.82 & 36.20 & 37.62 & 103.43 & 139.63 \\
$50 \%$ & 15.07 & 37.01 & 25.98 & 105.74 & 131.72 \\
$75 \%$ & 8.10 & 34.19 & 13.97 & 97.69 & 111.66 \\
$100 \%$ & 0 & 11.05 & 0 & 58.35 & 58.35 \\
\hline
\end{tabular}


The enitrification showed a downward trend with the increase of influent ratio in the Table 2. This is because the denitrification bacteria are heterotrophic bacteria, which use organic matter as the carbon source for growth and reproduction. With the increase of influent ratio, the concentration of organic matter gradually decreased, which led to the decrease of the activity of the denitrification bacteria. Although the removal rate of COD was reduced by denitrification, the removal rate of phenolic compounds and COD was positively correlated with the influent ratio in the figure 11 . This means in the anaerobic reactor, in addition to the presence of heterotrophic denitrification bacteria and anaerobic ammonium oxidizing bacteria, there are other heterotrophic anaerobic bacteria. This was similar to the results of the EGSB reactor studied by Qi Xuliang [13], and the coupling of the anaerobic reactor investigated by $\mathrm{Zu} \mathrm{Bo[14].} \mathrm{The} \mathrm{activity} \mathrm{of} \mathrm{heterotrophic} \mathrm{anaerobic} \mathrm{bacteria} \mathrm{might}$ increase with the increase of influent ratio. It seemed that denitrifying bacteria mainly used phenolic compounds as organic substrate by analyzing influent phenol concentration and denitrifying removal of COD. In most cases, the presence of phenolic compounds inhibits the activity of anaerobic ammonium oxidizing bacteria, but the inhibition could be relieved by domestication, forming strong resistance to phenol of the anaerobic ammonium oxidizing bacteria [15].

\subsection{Discussion of $R$ on anaerobic section effects}

From the Fig. 2 5 and Fig. 7 10, it can be seen that the removal rate was decreased and the other indicators of the removal rate of the basic and influent ratio was positively correlated and when the ratio increased from $75 \%$ to $100 \%$ except the total nitrogen and nitrite nitrogen increased, and the removal rate did not increase obviously. The favorite influent ratio was $75 \%$ accroding to the experiments. When the influent ratio was $75 \%$, the ratio of $\mathrm{C} / \mathrm{N}$ was 4.21 , and the removal rate of COD and ammonia nitrogen was the largest among ratios tested, which showed it is favoriable for COD and ammonia nitrogen remvoal in the lower $\mathrm{C} / \mathrm{N}$, which was beneficial to the coupling of anaerobic ammonium oxidation and denitrification. The results of this study were in acordance with that of Ran Chunqiu[16], that is, the removal of total nitrogen is the result of the coupling action of anaerobic ammonium oxidation and denitrification.

\section{Conclusions}

The following conclusion s can be drawn from the experiments:

(1) The coupling of anaerobic ammonium oxidation, heterotrophic denitrification and heterotrophic anaerobic process can be achieved using simulated coal gasification wastewater at the temperature of $35 \mathrm{C}$, the influent $\mathrm{pH}$ value around 7.0, HRT of the $30 \mathrm{~h}$, COD concentration of $800 \sim 1200 \mathrm{mg} / \mathrm{L}$. The results of TN removal is combined action of heterotrophic denitrification and anaerobic ammonium oxidation, and the removal of COD was the results of the cooperation and competition between heterotrophic denitrification and heterotrophic anaerobic bacteria.

(2) There are cooperation and competition in anaerobic ammonium oxidation, heterotrophic denitrification and anaerobic bacteria coupled anaerobic system. The influent ratio can change the synergy and competition effect among the three. Under the influent ratio of $75 \%$, the coupling effect of heterotrophic denitrification and anaerobic ammonium oxidation was the best, and the removal rate of TN was $64.56 \%$. The coupling effect of heterotrophic denitrification bacteria and heterotrophic anaerobic bacteria is also good as well, the COD removal rate is $80.1 \%$ and COD removal rate was only $1.38 \%$ lower than that at $\mathrm{R}$ of $100 \%$.

(3) At the influent ratio was $75 \%$, the removal of nitrogen by denitrification accounts for $32.39 \%$ of TN removal rate and the removal of nitrogen by anaerobic ammonium oxidation accounts for $67.72 \%$ of TN removal, when the consumption of $\mathrm{NH}_{4}{ }^{+}-\mathrm{N}$ and $\mathrm{NO}_{2}{ }^{-}-\mathrm{N}$ are $42.02 \mathrm{mg} / \mathrm{L}, 63.57 \mathrm{mg} / \mathrm{L}$, respectively. That is, consumption ration of $\mathrm{NH}_{4}{ }^{+}-\mathrm{N} / \mathrm{NO}_{2}{ }^{-}-\mathrm{N}$ is 1.51 . The amount of COD consumed by denitrification was $111.66 \mathrm{mg} / \mathrm{L}$, which accounted for $15.48 \%$ of the total amount of COD removal. The contribution rate of heterotrophic anaerobic bacteria to COD removal was $84.52 \%$, among them, the heterotrophic denitrification bacteria are mainly phenol denitrification bacteria. 


\section{Acknowledgement}

The project was financially supported by the Science and Technology Department of Jilin Province (Provincial Science Foundation Project No.20150101090JC).

\section{References}

[1] Pongsak N, Siriporn S, Mongkol D, et al. Anaerobic ammonium oxidation by Nitrosomonas spp and anammox bacteria in a sequencing batch reactor, J. Journal of Environmental Management. 2009, (90): 967-972.

[2] Chamchoi N, Nitisoravut S , Schmidt J E. Inactivation of ANAMMOX communities under concurrent operation of anaerobic ammonium oxidation (ANAMMOX) and denitrification, J. Bioresource Technology. 2008, (99): 3331-3336.

[3] Lu H F, Ji Q X, Ding S, et al. The morphological and settling properties of ANAMMOX granular sludge in high-rate reactors, J. Bioresource Technology. 2013, (143 ): 592-597.

[4] Sarina J, Siegfried E V, Eberhard M, et al. Successful application of nitritation/anammox to wastewater with elevated organic carbon to ammonia ratios, J. Water Research. 2014, (49): 316-326.

[5] Catarina T, Catarina M, Samantha B J, et al. The contribution of anaerobic ammonium oxidation to nitrogen loss in two temperate eutrophic estuaries, J. Estuarine, Coastal and Shelf Science. 2014, (143): 41-47.

[6] Li Yafeng, Zhang Xiaoning, Chen Wentong, et al.Experimental study on the performance of anaerobic ammonium oxidation and denitrification in the presence of organic carbon source, J. Environmental Engineering. 2012,31(1): 35-39.

[7] Zhuang H F, Han H J, Jia S Y, et al. Advanced treatment of biologically pretreated coal gasification wastewater using a novel anoxic moving bed biofilm reactor (ANMBBR) biological aerated filter (BAF) system, J. Bioresource Technology. 2014, (157): 223-230.

[8] Wang W, Han H J. Recovery strategies for tackling the impact of phenolic compounds in a UASB reactor treating coal gasification wastewater, J. Bioresource Technology. 2012, (103): 95-100.

[9] Fang F, Han H J, Zhao Q, et al. Bioaugmentation of biological contact oxidation reactor (BCOR) with phenol degrading bacteria for coal gasification wastewater (CGW) treatment, J. Bioresource Technology. 2013, (150): 314-320.

[10] Jin R C, Ma C, Yu J J. Performance of an Anammox UASB reactor at high load and low ambient temperature, J. Chemical Engineering Journal. 2013,(232): 17-25.

[11] Yang Yang, Zuo Jianer, Shen Ping, et al. Effects of temperature, $\mathrm{pH}$ value and organic matter on the activity of anaerobic ammonium oxidation, J. Environmental Science. 2006, 27(4): 691-695.

[12] Liu Changjing, Li Zebing, Zheng Zhaoming. Effects of phenol on the starting and nitrogen removal performance of anaerobic ammonium oxidation process, J. China Environmental Science. 2014, 35(5): 1145-1151.

[13] Qi Xuliang. EGSB reactor in tannery wastewater methanation, denitrification and anaerobic ammonium oxidation coupling research, D. Nan Jing: Nanjing University, 2013.

[14] Zu Bo, Zhang Daijun, Zhang Ping, et al. Factors affecting the coupling of anaerobic ammonium oxidation and methane denitrification, J. Journal of applied and Environmental Biology, 2007, 13(3): 438- 442. 
[15] Liu Changjing, Li Zebing, Zheng Zhaoming. Effect of different organic compounds on anaerobic ammonium oxidation coupled denitrification, J. China Environmental Science. 2015, 35(1): 87-94.

[16] Ran Chunqiu, Ge Hui, Zhao Budiao. Effects of different $\mathrm{C} / \mathrm{N}$ on anaerobic simultaneous nitrification and denitrification of activated carbon particles, J. Journal of Dalian Nationalities University, 2015, 17(3): 211-214. 